IJMS 20 (2), (105-127) (2013)

\title{
THE WEALTH EFFECTS OF SHARE REPURCHASES IN MALAYSIA
}

\author{
ROHAIDA ABDUL LATIF \\ KAMARUN NISHAM TAUFIL MOHD \\ WAN NORDIN WAN HUSSIN \\ KU NOR IZAH KU ISMAIL \\ UUM College of Business \\ Universiti Utara Malaysia
}

\begin{abstract}
This study aims to assess whether buyback activities in Malaysia are able to provide any economic benefits to shareholders both in the short-term and in the long-run. Specifically this study investigates the price effects on: (a) the announcement surrounding the repurchase intentions and implementation dates, (b) factors affecting the price effects on implementation dates and (c) long-run price effects subsequent to repurchase implementation. Using event study methodologies, this study finds no significant immediate price reactions surrounding repurchase intention dates. However, there is significant evidence of positive abnormal returns in days -5 to +5 surrounding the announcement of repurchase implementation. As for the factors affecting abnormal returns, this study finds that abnormal return responds positively to better prior price performance, dividend yield, directors' holdings, and fraction of shares repurchased. However, abnormal return responds negatively to the previous amount of cash held, reported earnings per share, and market-to-book value. Using a three year period as a measure of long-run, this study finds that there is no evidence that repurchasing firms experience superior or inferior price performance. This is one of the first studies in Malaysia to examine the long- run wealth effects of share repurchase.
\end{abstract}

Keywords: Share buybacks, shareholders' wealth, corporate finance, longrun performance, emerging, Malaysia.

\section{Introduction}

Share repurchases or share buybacks were legally allowed in Malaysia following the Asian financial crisis in 1997. In 1999, there were only 16 firms that announced their repurchase intentions. In 2005, the number 
of firms that engaged in repurchase announcements had increased to 206, an increase of more than tenfold.

Malaysia provides a unique setting to look at the announcement effects of repurchases since there are rules that have to be complied with. Before a firm could begin repurchasing its shares, it is required to submit a proposal of the repurchase intention to Bursa Malaysia and get shareholders' approval through an extraordinary general meeting (EGM) or the annual general meeting (AGM) whereby at least 75 per cent shareholders' approval must be obtained. However, this mandate is only valid for a maximum of one year until the next shareholders' meeting. Furthermore, regulations do not allow a listed company to buy back more than 10 per cent of its issued and paid up capital or to hold more than 10 per cent of its shares as treasury shares. Getting shareholders' approval does not mean that a firm has to engage in repurchase activities. Thus, there are many companies in Malaysia that ask for shareholders' approvals but never go ahead with the actual repurchases. Abdul-Latif (2010) reports that out of 281 nonfinancial companies that obtained approvals from their shareholders, 130 companies never repurchased their shares while 70 companies repurchased less that 2 per cent of their shares cumulatively from 1999 to 2006. Since a firm is allowed to announce its intention of repurchasing every year without even following through with actual repurchases, the first announcement might have little information effect.

It can be argued that the announcements of actual repurchases have more information content compared to the announcement of repurchase intention as firms are backing up their claim of undervaluation with actions. Thus, to measure the wealth effects of repurchases, this study looks at both intention announcements and actual announcements of the very first repurchase as information content of subsequent repurchases might have been impounded into prices (Schipper \& Thompson, 1983). Studies on actual repurchases are not as prevalent as studies on the announcement of repurchase intentions. The main reason is that the dates of actual repurchases cannot be ascertained. However, Malaysia is among the countries that require repurchasing firms to disclose their repurchase activities. For these countries, then, it is possible to measure the announcement effects of actual repurchases. The first part of this study then looks at the price effects following first announcements of intention to repurchase and first announcements of actual repurchase. 
In terms of ownership, since an average firm is tightly controlled by major shareholders, who in many cases also served on the board of directors, there are three major concerns. The first concern is that repurchases could be used to manipulate share prices to the benefits of the majority shareholders. In fact, this is a major concern of regulators. That might be the reason that before a repurchase could be carried out, it must get the approval from at least 75 per cent of the firm's shareholders, which means that it will not squeeze out the minority shareholders from decision-making. If this concern is valid, we should find that directors' holdings would affect announcement returns negatively. The second concern is that since directors hold, based on this study, about 42 per cent of the shares, false signalling might be a concern. A firm might falsely signal that it is undervalued when in fact it is not undervalued. Since firms in Malaysia are required to report to Bursa Malaysia, or the Malaysia Stock Exchange, about their repurchases, resale, or cancellation of repurchased shares no later than $6.30 \mathrm{p} . \mathrm{m}$. on the date of repurchases, false signalling could be tested. Two variables are used to test for signalling; one is the performance of the share prices 60 days before repurchases and the other is the fraction of shares repurchased in the year of repurchases. The third concern is that since directors' wealth is tied up in the stock performance of a firm, and since prices reflect dividends, which are related to earnings, then there might be a higher tendency of firms to manage their earnings. By studying circulars to shareholders, Nasaruddin and Angappan (2004) find that firms engaged in repurchases to improve their reported EPS. In an efficient market, earnings manipulation would not lead to positive returns. Thus the second part of this study looks at firm characteristics or factors that influenced abnormal returns following actual repurchase announcements.

One of the reasons given by managers in Malaysia to justify repurchases, as mentioned in circulars to shareholders, is to stabilize share prices. Thus, it is important that price performance is measured over a longer period. Thus for the third part, this study investigates the long-run performance, which is measured over a period of 36 months following the actual repurchases. There is inconclusive evidence regarding whether repurchasing firms experience superior performance in the long-run. Ikenberry, Lakanishok, and Vermaelen (1995 and 2000) and Jaganathan and Stephens (2003) find that there exist long-term return drifts following open market repurchase announcements suggesting that the initial market reaction is incomplete. This implies that the economic benefit of repurchase may 
not be fully realized immediately, but perhaps over a longer horizon. Ikenberry et al. (1995) and Ikenberry and Vermaelen (1996) believe that the long-term value of open market repurchase is very much dependent on the ability of managers to take advantage of valuation errors. Ikenberry et al. (1995) finds that on average repurchasing firms gained significant returns of 73.75 per cent while non-repurchasing firms experienced returns of 61.15 per cent, a marked difference of 12.6 per cent in excess returns over a 3-year period. This finding suggests that managers of repurchasing firms are indeed correct about market-mispricing of their shares. Chan, Ikenberry, and Lee (2004) and Zhang (2005) also provide consistent findings. The fact that repurchasing firms experienced low abnormal returns prior to repurchase announcement but high abnormal returns after actual repurchase dates suggests that the market does not fully anticipate the long term economic benefits of repurchase. On the contrary, McNally and Smith (2007) using the Canadian repurchase dataset from 1987 to 2000 demonstrate that there are no long-run abnormal returns evidenced after repurchase announcements and implementation if transaction costs are considered.

\section{Literature Review}

This section discusses the literature related to the three objectives mentioned in the previous section. The first subsection looks at the literature on announcement effects of repurchases, the second subsection looks at the characteristics that influenced abnormal returns, while the last part discusses the literature on long-run performance.

\section{Announcement Effects of Repurchases}

Studies in the US find significant positive abnormal returns surrounding repurchase announcements (see, for example, Comment \& Jarrell, 1991; Ikenberry et al., 1995; Vermaelen, 1981). Studies show that the impact on returns would tend to depend on the type of repurchases employed; whether tender offers or open market (Lie, 2002; Vermaelen, 1981). The larger the size of repurchases, the bigger the impact would be on the firms' returns. On average, the proportion of shares bought back by the US firms either through open market repurchases or tender offers was 5 per cent and 15 per cent respectively. As open market repurchases usually involve a smaller number of shares bought as compared to other methods of 
repurchases, it is expected that open market repurchases would lead to marginal changes in prices. For example, Lie (2002) reports that gain from tender offer repurchases is a statistically significant 8 per cent over a 3-day window period while Dann (1981) finds a mean rate of return of more than 3 per cent following the announcement of open market repurchases in the US for a 2-day window period. Vermaelen (1981) finds that on average, tender offer repurchases experienced a significant positive CAR of 15.7 per cent while open market repurchases gain a positive CAR of 3.62 per cent in a 16-day window period, $(-5,+10$ days $)$.

Mohamad Jais and Chin (2001), Lim and Bacha (2002) and Mansor, Zaidi and Swee Peng (2011) look at the announcement effects of repurchase programmes in Malaysia. These studies document that the market reacts positively to the announcements of repurchase which is consistent with the signalling hypothesis. On the other hand, Hanita (2004) finds that there is zero abnormal returns for repurchase announcements involving Malaysian companies. The difference in the results between these Malaysian studies might be due to the different periods, sample size, and methods employed.

In Hong Kong, Zhang (2005) investigates share price performance of 135 actual repurchases between September 1993 and August 1997. He finds that the market responds favourably following the actual implementation of repurchase as evidenced by a statistically significant positive mean CAR of 0.43 per cent in a three-day period from the announcement date to two days after the announcements. The mean CAR experienced by Hong Kong firms is economically small as compared to those experienced by the US.

\section{Factors Influencing Abnormal Returns}

It is expected that abnormal returns of a repurchase firm $i$ from time $t_{1}$ to $t_{2}, C A R_{i, 11,2^{2}}$ is related to the firm's financial characteristics (see, for example, Chan et al., 2004; Grullon \& Michaely, 2004; and Zhang, 2005). The undervaluation hypothesis states that firms engaged in share repurchase when they perceived that their shares are undervalued. If investors believe in the hypothesis, then prior returns (CAR60D) would affect CAR negatively with poor priceperforming firms earning higher returns on announcements. Ho, Liu and Ramanan (1997), Stephens and Weisbach (1998) and Chan et al. (2004), among others, find that abnormal returns are negatively related to past return-performance, which provides support for the 
undervaluation hypothesis. The effect of operating performance, as measured by LYEBITDA, on CAR is expected to be positive as firms with better performance could afford to repurchase more of their shares.

The expected sign of LYCASH is positive given that firms with higher free cash flows could spend more to repurchase their shares. Jensen (1986) argues that firms with excess cash might spend the cash on nonprofitable activities. However, given that firms in Malaysia are tightly held, the tendency to misuse the excess funds might be alleviated. In this case, one might observe that firms with excess cash might use it to repurchase their shares. Thus, it is expected CAR to be positively related to cash flows.

Repurchase could be used as a tool to manage earnings per share. If a firm uses repurchases to influence its earnings per share, investors will interpret the repurchases as evidence of lower future earnings. Thus CAR is negatively related to EPS as measured by LYEPS. Director ownership, as proxied by LYDIR, is expected to influence CAR positively. The larger the director ownership, the greater is the wealth of the directors tied up with the performance of the firm. Therefore, if directors believe that their firm is undervalued, they have a greater incentive to signal to the market of the undervaluation through repurchases.

CAR is expected to be positively related to the size of the repurchase (PBTNOS). If managers believe that their firms' shares are undervalued and they are willing to spend a large amount of money to buy back their shares, then the action of buying back shares will send a credible claim that the firms' shares are indeed undervalued. Firms with more growth opportunities, as measured by LYMTBV, have more reason to retain their cash to finance their investments. Therefore, if they buy back their shares, their action will signal to the market that in the future, they will have less investment opportunities and thus, their stock prices will fall following the repurchases. Accordingly, CAR is negatively related to LYMTBV.

\section{Long-run Performance of Repurchasing Firms}

The long-term performance of open market repurchases depends on the ability of managers to take advantage of the valuation errors (Ikenberry et al., 1995; Ikenberry \& Vermaelen, 1996; Zhang, 2002). Ikenberry et al. (1995) argue that managers have timing ability and 
are almost always correct in their valuation. Their findings provide evidence that on average repurchasing firms gained significant returns of 73.75 per cent while non-repurchasing firms experienced returns of 61.15 per cent, a marked difference of 12.6 per cent in excess returns over a 3-year period. This finding suggests that managers of repurchasing firms are indeed correct about market mispricing of their shares. Chan et al. (2004) find that repurchasing firms exhibit significant positive cumulative abnormal performance of 23.56 per cent in 4 years following the announcement dates compared to nonrepurchasing firms. The fact that repurchasing firms experienced low abnormal returns prior to repurchase announcement but high abnormal returns after the announcement dates suggest that the market does not fully anticipate the long-term economic benefits of repurchases. Zhang (2005) also studies the long-term effects of firms that actually bought back their shares. He finds weak evidence that actual repurchasing firms experience better price performance in the long-run. He groups the sample firms into different clusters according to book-to-market value (BTMV) and finds that value firms (high BTMV ratios) perform significantly better than glamour firms (low BTMV) with abnormal returns of more than 20 per cent in a 3-year post actual implementation of repurchases. His findings suggest that at least value firms can deliver superior long-term performance to shareholders. Chan, Ikenberry, and Lee (2007) offer an extensive examination on post-announcement returns drift subsequent to repurchase announcements and implementations. Using a sample of 5508 repurchase programmes by the US firms between 1980 and 1996, they find significant evidence that repurchasing firms (announcers and implementers) outperform non-repurchasing firms. In addition, value firms that implement repurchase programmes and buy back more shares enjoy even higher abnormal returns in a four-year period subsequent to the announcement dates. On average, value firms experience positive cumulative abnormal returns of 56.54 per cent in a four-year period following repurchase announcements while growth firms experience a positive 47.05 per cent in the same period. However, McNally and Smith (2007) find that there is no long-run abnormal return after repurchase announcements and implementations if transaction costs are considered. Similarly, Bradford (2008) finds no support to long-term abnormal returns subsequent to open-market repurchase announcements.

The above discussion shows that there are mixed findings on the long-run performance of repurchasing firms. Furthermore, there is no study that measures long-run performance in Malaysia. This study 
fills in the void by providing evidence on the long-run performance from the perspective of a developing economy.

\section{Data and Methodology}

This study focused on all non-financial public listed Malaysian companies that have announced and actually bought back more than 1 per cent of their shares cumulatively from 1999 to 2006. This process produced 81 companies. However, four companies were excluded as their first announcement dates could not be obtained, leaving a total sample of 77 . To measure initial market reaction to repurchase announcements, the market model was employed. Two announcement dates were used. The first date was the first public announcements of the firms' repurchase intention. The intention date was the earliest date available to the public as gathered either from the firm's repurchase circular to the shareholders, firm's repurchase notes to Bursa Malaysia or Bursa Malaysia's approval date for the repurchase intention mentioned in each repurchase circular to the shareholders. The second date was the firm's first announcement of repurchase implementation or the actual repurchase. The actual repurchase date is the date when the firms report their actual buying back activities to Bursa Malaysia. These reports are available online.

Some researchers argue that there are no clear rules on how long the event and the estimation period should be (see, for example, McKinlay, 1997 and event study tools, 2014). It is reported that a longer periods may promise greater accuracy but they also bear the risk of covering structural breaks due to confounding events and information leakage (Event study tools, downloaded 2014). MacKinlay (1997) suggests that the event period should include at least the announcement date. He elaborates that the event period can be longer than the specific event of interests to sufficiently capture the price effects of the announcements. This study used the 121-day event period, a long window period, to adequately capture any significant price changes due to possible information leakage. The estimation period of the market model is from day-200 to day-61 before the announcement date.

To test whether factors mentioned in the literature influenced abnormal returns following actual repurchases, the following model is estimated. 


\begin{abstract}
CAR $_{\mathrm{i}}=\mathrm{b}_{0}+\mathrm{b}_{1}$ CAR60D $_{\mathrm{i}}+\mathrm{b}_{2}$ LYEBITDA $_{\mathrm{i}}+\mathrm{b}_{3}$ LYCASH $_{\mathrm{i}}+\mathrm{b}_{4}$ DYIELD $_{\mathrm{i}}+$ $b_{5}$ LYEPS $_{i}+b_{6}$ LYDIR $_{i}+b_{7}$ LYMTBV $_{i}+b_{8}$ PBTNOS $_{i}+e_{i}$ Where, $^{2}$

$\mathrm{CAR}_{i}=$ Cumulative abnormal returns of firm $i$ from one day before to one day after the announcement (day -1 to +1 ) of repurchase implementations of firm $i$.

$\mathrm{CAR60D}_{i}=$ Cumulative market adjusted abnormal return in the previous 60 days before the announcement of repurchase implementations.

LYEBITDA $_{i}=$ Last year EBITDA of firm $i$, where EBITDA is the ratio of earnings before interest, taxes, depreciation and amortization to total assets.

$\mathrm{LYCASH}_{i}=$ Last year cash holding ratio of firm $i$.

DYIELD $_{i}=$ Dividend yield of firm $i$. Dividend yield is calculated as cash dividends paid scaled by the firm's market value of equity.

LYEPSi $=$ Last year EPS of firm $i$.

LYDIR $_{\mathrm{i}}=$ The total percentage of share held by directors of firm $i$ (directly and indirectly) in the previous year.

$\mathrm{LYMTBV}_{\mathrm{i}}=$ Prior year firm $i$ market value to book value of equity. PBTNOS $_{i}=$ The actual number of shares bought back by firm $i$ during the year scaled by ordinary shares outstanding.
\end{abstract}

To measure long-run performance, cumulative average abnormal returns (CAAR) and buy and hold returns (BHAR) are estimated over a 3-year period subsequent to repurchase implementations.

\title{
Findings and Discussion
}

\section{Announcement Effects on Intention Date}

Table 1 shows that that the cumulative average abnormal return (CAAR) is negative prior to the announcement of repurchase intentions as measured by the event window of day- 60 to -1 . During this period, the market model shows a return of -3.7 per cent though it is not statistically significant. This result is consistent with the findings documented in previous studies that repurchase announcements were preceded by poor price performance (see, for example, Zhang, 2005; and Ikenberry et al., 1995). As for performance after the 
announcement of repurchase intentions, there is a significant positive abnormal return of 7.1 per cent in the 61-day period starting from the announcement date. When shorter window periods are used, there is no evidence of significant abnormal returns. Abnormal returns over a 3-day, 7-day and 11-day periods surrounding the announcement of repurchase intentions are -0.07 per cent, -0.09 per cent and 1.42 per cent respectively and they are all not significant at 10 per cent level.

Table 1

CAAR Surrounding Repurchased Intentions

\begin{tabular}{cccl}
\hline Window period & CAAR & Z-score & p-value \\
\hline$-60,+60$ & 0.034054 & 0.897023 & 0.369707 \\
$-60,-1$ & -0.036682 & -1.372138 & 0.170021 \\
$0,+60$ & 0.070736 & 2.624217 & $0.008685^{* * *}$ \\
$-5,+5$ & 0.014158 & 1.236845 & 0.216145 \\
$-3,+3$ & -0.000958 & -0.104916 & 0.916442 \\
$-1,+1$ & -0.000704 & -0.117788 & 0.906235 \\
$0,+3$ & 0.000113 & 0.016302 & 0.986994 \\
AAR day 0 & 0.00165 & 0.47913 & 0.63184 \\
AAR day +1 & -0.00064 & -0.18459 & 0.85355 \\
\hline
\end{tabular}

*** denotes significant at $1 \%$ level.

Overall, it can be said that the market is not surprised by the announcement of repurchase intentions. This is partly due to the Malaysian policy regarding repurchase. It is mandatory for listed firms to submit their annual repurchase intentions to Bursa Malaysia and table them in their annual general meeting (AGM) prior to repurchase implementation. Since implementation of repurchase programmes are not mandatory, many firms regard the announcement of repurchase intentions as routine and therefore these announcements are usually squeezed in the firms' AGM agenda.

\section{Price Reactions on Actual Repurchase Dates}

This section presents the price effects associated with the firms' announcement of repurchase implementation. To reduce the confounding effects associated with multiple repurchase announcements, this study uses only the first actual repurchase dates which are gathered from the "immediate announcement report" after the actual repurchase implementation are available 
through the Bursa Malaysia website. Table 2 summarizes CAAR during several window periods. CAAR prior to the announcement of actual repurchases, from -60 to -1 , is an insignificant -2.19 per cent. Similar to the announcement of repurchasing intentions, repurchase implementations are preceded by the underperformance of firms, even though it is not significant.

Table 2

CAAR Surrounding Repurchase Implementations

\begin{tabular}{lccc}
\hline Window & CAAR & Z-score & p-value \\
\hline$-60,+60$ & 0.015395 & 0.436259 & 0.662649 \\
$-60,-1$ & -0.021908 & -0.881635 & 0.377974 \\
$0,+60$ & 0.037302 & 1.488809 & 0.136538 \\
$-5,+5$ & 0.030316 & 2.849338 & $0.004381^{* * *}$ \\
$-3,+3$ & 0.030965 & 3.648303 & $0.000264^{* * *}$ \\
$-1,+1$ & 0.012053 & 2.169201 & $0.030067^{* *}$ \\
$0,+3$ & 0.025650 & 3.997885 & $0.000064^{* * *}$ \\
AAR day 0 & 0.006798 & 2.110250 & $0.027704^{* *}$ \\
AAR day +1 & 0.001125 & 0.349157 & 0.530661 \\
AAR day +2 & 0.008119 & 2.520281 & $0.009327^{* * *}$ \\
AAR day +3 & 0.008512 & 2.642364 & $0.006549^{* * *}$ \\
\hline$* * * * *$ denote significant at $10 \%, 5 \%$ and $1 \%$ level respectively.
\end{tabular}

Table 2 shows significant price reactions in several window periods. A significant average abnormal return of 0.68 per cent on the date of actual repurchase announcements is observed. This suggests that when firms start buying back their shares which conveys a strong signal that their shares are indeed undervalued, market starts reacting positively. It is also interesting to note that repurchase firms continue to experience significant positive AAR up to three days subsequent to the initial repurchase dates.

Table 2 also shows that abnormal returns are statistically significant in short window periods: $(-5$ to +5$),(-5$ to +5$),(-1$ to +1$)$, and $(0$ to +3$)$. In these periods, firms that announced repurchase implementation experience positive CAAR ranging from 2.6 to 3.1 per cent with 5 per cent significant level. The result is consistent with the findings in several studies; see, for example, Mansor, Ghani and Lee (2011), Zhang (2005), Chan, Ikenberry, and Lee (2004), and Jaganathan and Stephen (2003). However, the average abnormal returns appeared to be small 
in this study as compared to those experienced by repurchase firms in the US markets. Two explanations can be offered to explain the smaller returns in Malaysia. First, since the firms' actual repurchase transactions are partly anticipated, abnormal returns should be small in comparison to the unexpected announcement. In Malaysia, it is mandatory that firms got the Bursa's approval and shareholders' mandate prior to embarking on share repurchase. Second, given that on average the number of bought shares by Malaysian firms are small (on average it is about 1 per cent of outstanding shares) in comparison to those bought back in the US (on average it is about $6-7$ per cent of outstanding shares), then the price reaction would be smaller. The larger the number of shares bought back, the stronger the signal the firm is sending that its shares are undervalued and therefore the better the price reactions are.

Returns from four days to 60 days after the announcements of actual repurchase are an insignificant 2.05 per cent. This result is consistent with efficient market notion. In an efficient market, news should be impounded in prices around the announcement dates and there should not be any drift, either upward or downward, after the announcements.

\section{Factors Effecting Abnormal Returns}

It is expected that abnormal returns of a repurchasing firm $i$ from time $t_{1}$ to $t_{2}, \mathrm{CAR}_{\mathrm{i}, 11,2^{2}}$ is related to the firm's financial characteristics (see, for example, Chan et al., 2004; Grullon \& Michaely, 2004; and Zhang, 2005). A multivariate regression is then estimated to measure whether the financial characteristics affect the abnormal returns associated with actual repurchase announcements. For this study, the actual date of repurchase implementation is used rather than the announcement date. It is difficult to ascertain the exact first announcement date simply because there is a lot of noise associated with the proposed repurchase date. The first date of announcements is when firms seek approval to buy back shares from Bursa Malaysia. Then the firms would announce their intention to buy back their shares to their shareholders in their annual general meeting (AGM). It is also common to see firms announce their repurchase intentions in their firms' annual reports prior to the AGM meeting.

Table 3 shows the descriptive statistics for the 77 sample firms. On average, the percentage of shares repurchased is 2.2 per cent and the percentage of directors' shareholdings is relatively high at 42.2 
per cent. The shareholding patterns show that firms in Malaysia are tightly held. Firms tend to repurchase their shares when the past 60-day performance is negative. This might show that the firms are signalling that their shares are undervalued.

Table 3

Descriptive Statistics on Variables Used in the Regression Model

\begin{tabular}{lcccc}
\hline \multicolumn{1}{c}{ Variable } & Average & $\begin{array}{c}\text { Standard } \\
\text { deviation }\end{array}$ & Minimum & Maximum \\
\hline CAR(-1, +1) & 0.0124518 & 0.0527256 & -0.0815758 & 0.2597276 \\
CAR60D & -0.0143637 & 0.2211623 & -0.633133 & 0.468984 \\
LYEBITDA & 0.0657976 & 0.2018448 & -1.114434 & 0.326468 \\
LYCASH & 0.1289713 & 0.1265201 & 0.0002451 & 0.7773893 \\
DYIELD & 0.024774 & 0.0241205 & 0 & 0.10148 \\
LYEPS & 0.1382719 & 0.2489011 & -0.7289 & 1.404 \\
LYDIR & 0.4219852 & 0.1814069 & 0.000 & 0.7594 \\
LYMKTBV & 1.054416 & 0.8229384 & 0.24 & 5.96 \\
PBTNOS & 0.021954 & 0.0266927 & 0.00002 & 0.17018 \\
\hline
\end{tabular}

Table 4 summarises the results of the regression analysis. Based on the undervaluation hypothesis, it is expected that prior price performance would negatively affect the abnormal returns. However, it is found that the 60-day return prior to the actual repurchase dates (CAR60D), a measure of undervaluation, positively affects price performance. This result shows that investors reacted positively to repurchase implementations of firms that had better prior price performance and this contradicts the findings of, among others, Ho et al. (1997), Stephens and Weisbach (1998) and Chan et al. (2004). One possible explanation is that since firms in Malaysia are tightly held and owners' wealth is tied up to the firms' price performance, investors are wary those firms would use repurchases to manipulate their share prices. Thus, even though repurchases are welcomed, investors reacted more positively to repurchases initiated by firms that had better prior price performance. It seems that signalling by prior price performance does not lead to higher price for firms with poor prior price performance.

Even though the sign of operating performance, as measured by the prior year firms' profit level (LYEBITDA), is positive it is not significant. Contrary to expectation, prior cash holdings, LYCASH, 
have a negative effect on abnormal returns. One possible explanation is that firms with large cash holdings that undertake repurchases are sending a signal to investors that they have less investment opportunities in the future. Thus, investors react negatively to their actions of buying back shares.

Table 4

Regression Results

\begin{tabular}{lccc}
\hline Variable & Coefficient & t-stat & p-value \\
\hline Constant & -0.0288 & -1.26 & 0.212 \\
CAR60D & 0.0273 & 1.68 & $0.097^{*}$ \\
LYEBITDA & 0.0098 & 0.48 & 0.633 \\
LYCASH & -0.0711 & -2.68 & $0.009^{* * *}$ \\
DYIELD & 0.4422 & 1.90 & $0.062^{*}$ \\
LYEPS & -0.0448 & -2.41 & $0.019^{* *}$ \\
LYDIR & 0.0788 & 2.42 & $0.018^{* *}$ \\
LYMTBV & -0.0096 & -2.05 & $0.045^{* *}$ \\
PBTNOS & 1.0166 & 2.83 & $0.006^{* * *}$ \\
F-stat & $4.35(\mathrm{p}-\mathrm{value}=0.0003)$ & \\
R-squared & 0.343 & & \\
$*^{* * * * * *}$ denote significant at $10 \%, 5 \%$, and $1 \%$ respectively.
\end{tabular}

Dividend yield (DYIELD) affects abnormal returns positively. LYDYLD is used as a measure of growth opportunities. High dividend yield firms are considered to have less growth opportunities. Therefore, for these firms, if they undertake repurchases, investors would react positively since free cash would not be used to finance negative net present value projects. The prior year reported EPS (LYEPS) negatively affects abnormal returns. It seems that investors interpret that firms are manipulating their EPS through repurchases. Therefore, investors react negatively to repurchase implementations. This result demonstrates that it does not pay to manipulate EPS. As expected, director holdings (LYDIR) positively affect price reactions of repurchases. Thus, the concern that directors might act on their own self-interests at the expense of the minority shareholders is unfounded. The firm's growth opportunities as measured by LYMTBV negatively affect abnormal returns as hypothesised. Repurchases initiated by high growth firms are interpreted as a signal of lower growth opportunities in the future and consequently, abnormal returns are lower. The amount of shares bought back during the year 
as measured by PBTNOS significantly affects abnormal returns. This shows that the greater the number of shares repurchased, the stronger is the signal that the shares are traded below their intrinsic value, thus the better the abnormal returns would be. Therefore, the percentage of shares repurchased could be used to signal either undervaluation or better future performance.

\section{Long-run Price Performance}

The sample in the long-run price performance uses the firms that bought back their shares, from the previous section. Monthly prices of all the 77 firms are gathered from one month prior to the first actual repurchase dates to 36 months post actual repurchase dates ( -1 to +36 months). This study employed two methods of abnormal returns which were: (a) cumulative average abnormal returns (CAAR) and (b) buy and hold returns (BHAR).

The returns of the repurchasing firms have to be compared against some benchmark to measure the performance of the repurchasing firms. Two benchmarks for price performance are applied: (a) the market benchmark approach using the Bursa Malaysia Composite Index (KLCI) and (b) the matching firm approach as recommended by Barber and Lyon (1997). To identify matching firms, market value and market-to-book value of each repurchasing firm in the month prior to the actual repurchase month would be matched against those of other firms. Firms with the lowest Euclidean distance are chosen as matching firms. Euclidean distance is measured in the following manner:

$\mathrm{D}=\left(\frac{M V i}{\sum_{i=1}^{n} M V i}-\frac{M V b}{\sum_{i=1}^{n} M V i}\right)^{2}+\left(\frac{M T B V i}{\sum_{i=1}^{n} M T B V i}-\frac{M T B V b}{\sum_{i=1}^{n} M T B V i}\right)^{2}$

where,

$\mathrm{MV}_{b} \quad$ : Market value of repurchasing firm $b$ in the month prior to the month of actual repurchase

$\mathrm{MV}_{i}$ : Market value of firm $i$

$\mathrm{MTBV}_{b}$ : Market-to-book value of repurchasing firm $b$ in the month prior to the month of actual repurchase

$\mathrm{MTBV}_{i}: \quad$ Market-to-book value of firm $i$ 
Three groups of matching firms are used which are: (a) 1-match firm, (b) 2-match firms and (c) 4-match firms. Matching is done one month before the first actual repurchase dates. Long-run performance might also be influenced by the way the adjusted returns are weighted. Therefore, both equal-weighted and value-weighted measures are used to investigate the effects of size on long-run performance.

Table 5 summarizes the goodness of fit between repurchasing firms and matching firms. The average market value of the repurchasing firms is RM558.5453 million and the market-to-book value is 1.0665. If matching is done on a one-to-one basis, then the average market value and the market-to-book value of the matching firms are RM545.2309 million and 1.0317 respectively. The paired sample difference in means is not significant for both variables with the p-values of the differences in market value and the market-to-book value of 0.9353 and 0.77478 respectively. Therefore, the null hypotheses that the characteristics of the matching firms are similar to those of the repurchasing firms cannot be rejected. As the number of matches is increased, the differences between repurchasing firms and their matches are still not significant. Thus, it shows that the characteristics of the matches reflect the characteristics of the repurchasing firms.

Table 5

Goodness-of-Fit of the Matching Firms

\begin{tabular}{lcccccc}
\hline & $\begin{array}{c}\text { MV of } \\
\text { repurchasing } \\
\text { companies }\end{array}$ & $\begin{array}{c}\text { MV of } \\
\text { matching } \\
\text { companies }\end{array}$ & $\begin{array}{c}\text { P-value of } \\
\text { difference } \\
\text { in MV }\end{array}$ & $\begin{array}{c}\text { MTBV of } \\
\text { repurchasing } \\
\text { companies }\end{array}$ & $\begin{array}{c}\text { MTBV of } \\
\text { matching } \\
\text { companies }\end{array}$ & $\begin{array}{c}\text { P-value of } \\
\text { difference } \\
\text { in MTBV }\end{array}$ \\
\hline 1- match & 558.5453 & 545.2309 & 0.9353 & 1.0665 & 1.0317 & 0.7747 \\
2- match & 558.5453 & 543.2732 & 0.9260 & 1.0665 & 1.0334 & 0.7819 \\
4- match & 558.5453 & 518.6670 & 0.7963 & 1.0665 & 1.0253 & 0.7248 \\
\hline
\end{tabular}

*, indicates significant at $10 \%$ level (2-tailed tests).

MV is market value while MTBV stands for market-to-book value. $\mathrm{P}$-value of difference in variable is based on t-test of the difference in paired samples between repurchasing firms and their matches. In case of two or four matches per repurchasing firm, the difference is calculated by taking the difference between average value of the matches and the repurchasing firm.

Table 6 presents the buy-and-hold returns (BHAR) over the 36-month period. Both equal-weighted (EW) and value-weighted (VW) buyand-hold raw returns, summarized in columns 1 and 2 respectively, 
show that after the actual implementation of repurchases, share prices of the repurchasing firms increase.

At the end of the three-year period, the EW raw return is 14.39 per cent, which is significant at 10 per cent level, and the VW raw return is 17.80 per cent, which is significant at 5 per cent level. Thus it seems that managers repurchased their firms' shares when they believed that the shares were undervalued. However, when a firm's raw returns are adjusted using a benchmark's returns, the results do not become significant over the three-year period. Columns 3 and 4 show the EW and VW buy-and-hold abnormal returns when the Bursa Malaysia Composite Index is used as the benchmark. Even though the EW BHAR at the end of the 30-month period of -13.56 per cent is marginally significant at 10 per cent, it is not becoming significant over the three year period. However, the VW BHAR is not significant at the end of 30-month or 36-month period. Thus it seems that the underperformance of the EW-BHAR is driven by small firms. When the sample is divided into two groups based on size, the group of smaller firms shows an underperformance of -23.11 per cent over a 36-month period, when the EW approach is used, and the underperformance is significant at 10 per cent while the group of larger firms shows an insignificant abnormal return of -2.55 per cent. The results are summarized in Table 7.

When matching firms are used as the benchmarks, the results are similar to those of the Bursa Malaysia Composite Index, i.e. the performance of repurchasing firms does not differ from the performance of matching firms over the three-year period, irrespective of the number of matching firms that is used. Columns 5 to 10 of Table 6 summarize the results when matching firms are used. However, it is interesting to note that the underperformance of the VW BHAR is driven by larger firms when matching firms are used as the benchmarks as compared to the previous result when the Bursa Malaysia Composite Index is used as the benchmark.

Table 6 documents that there are no significant abnormal returns gained for repurchasing firms over the long-run (30 to 36 months) regardless of the groups used with the exception of the index-matching EW-BHAR. It is argued that the result for the index-matching EWBHAR could be driven by firm size. Table 7 demonstrates the effect of firm size on the firm's abnormal returns after firm size has been considered. It is found that there was no difference in abnormal returns gained by large companies over the long-run, but small firms experienced significant negative returns. Therefore, the significant negative abnormal returns experienced by the EW BHAR were indeed driven by company size. 
IJMS 20 (2), (105-127) (2013)

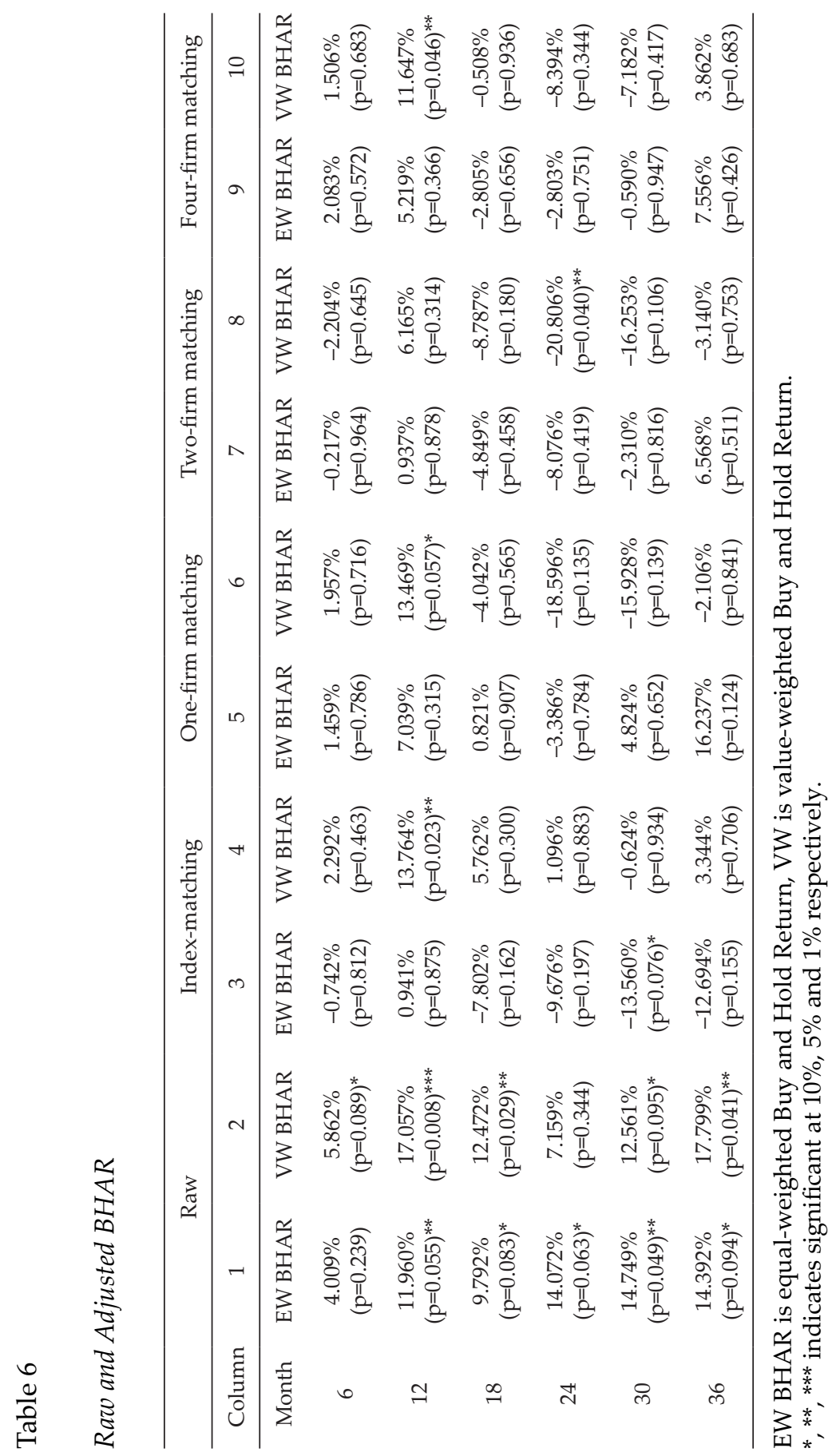


Table 7

BHAR Based on Equal-Weighted Approach of Small and Large Repurchasing Firms when Bursa Malaysia Composite Index is Used as the Benchmark

\begin{tabular}{ccccc}
\hline \multirow{2}{*}{ Month } & \multicolumn{2}{c}{ Small firms $(\mathrm{n}=38)$} & \multicolumn{2}{c}{ Large firms $(\mathrm{n}=39)$} \\
\cline { 2 - 5 } & BHAR & P-value & BHAR & P-value \\
\hline 6 & $-2.784 \%$ & 0.510 & $1.247 \%$ & 0.789 \\
12 & $-7.900 \%$ & 0.141 & $9.555 \%$ & 0.366 \\
18 & $-16.814 \%$ & $0.024^{* *}$ & $0.978 \%$ & 0.906 \\
24 & $-20.713 \%$ & $0.036^{* *}$ & $1.077 \%$ & 0.924 \\
30 & $-20.432 \%$ & $0.062^{*}$ & $-6.863 \%$ & 0.526 \\
36 & $-23.109 \%$ & $0.073^{*}$ & $-2.545 \%$ & 0.839 \\
\hline
\end{tabular}

$*, * * * * *$ indicate significant at $10 \%, 5 \%$, and $1 \%$ levels respectively.

Table 8 presents the cumulative average abnormal returns (CAAR) over the 36-month period. The results are similar to those of BHAR. As for the raw returns, it seems that managers repurchased their firms' shares when they believed that the shares were undervalued. Both the EW and VW CAAR are significant over the three-year period with the EW CAAR showing a return of 17.06 per cent and the VW CAAR showing a return of 22.67 per cent. Both returns are significant at 1 per cent-level. However, when the repurchasing firms' returns are adjusted using benchmarks, the return over the three-year period is not significant. Similar to the results of BHAR, the underperformance of the EW CAAR compared to the VW CAAR is driven by smaller firms when the Bursa Malaysia Composite Index is used as the benchmark (refer to Table 9) and the underperformance of the VW CAAR is driven by larger firms when matching firms are used as the benchmarks. Therefore, it can be concluded that the results of the long-run performance show that there is no different in price performance between repurchasing firms and their benchmarks, irrespective of the types of benchmarks being used. This finding is consistent with the findings of McNally and Smith (2007). This finding shows that the market in Malaysia is efficient in terms of the long-run performance of repurchasing firms. 


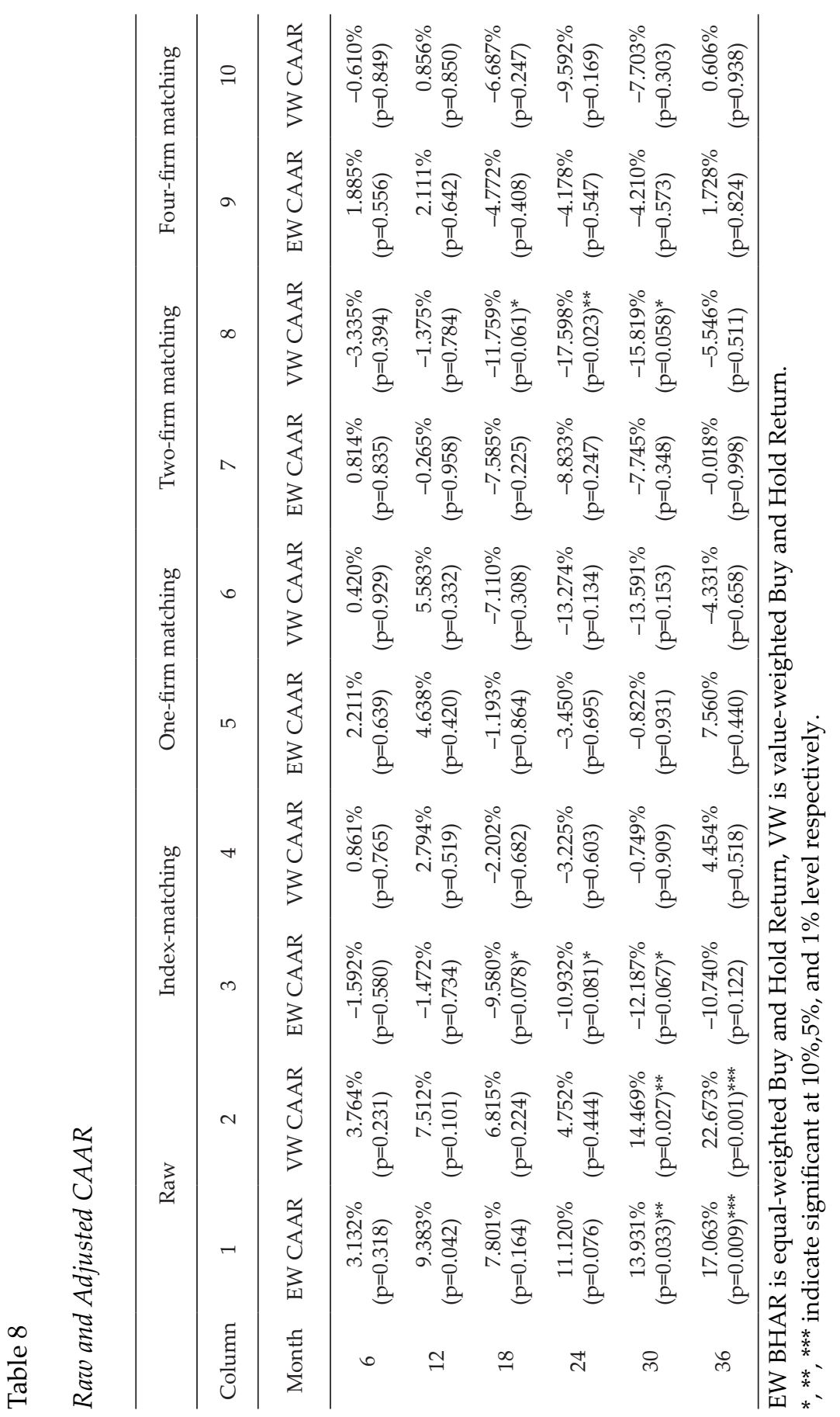


Table 9

CAAR Based on Equal-Weighted Approach of Small and Large Repurchasing Firms when Bursa Malaysia Composite Index is Used as the Benchmark

\begin{tabular}{ccccc}
\hline \multirow{2}{*}{ Month } & \multicolumn{2}{c}{ Small firms $(\mathrm{N}=38)$} & \multicolumn{2}{c}{ Large firms $(\mathrm{N}=39)$} \\
\cline { 2 - 5 } & CAAR & P-value & CAAR & P-value \\
\hline 6 & $-3.178 \%$ & 0.443 & $-0.046 \%$ & 0.991 \\
12 & $-5.711 \%$ & 0.250 & $2.659 \%$ & 0.709 \\
18 & $-14.728 \%$ & $0.027^{* *}$ & $-4.564 \%$ & 0.597 \\
24 & $-16.473 \%$ & $0.039^{* *}$ & $-5.534 \%$ & 0.568 \\
30 & $-15.770 \%$ & $0.082^{*}$ & $-8.697 \%$ & 0.379 \\
36 & $-18.022 \%$ & $0.064^{*}$ & $-3.644 \%$ & 0.715 \\
\hline
\end{tabular}

$*, * *, * *$ indicate significant at $10 \%, 5 \%$, and $1 \%$ levels respectively.

\section{Conclusion}

This study addresses three main issues regarding the price impacts of repurchasing activities which are: (a) price performance surrounding the announcement of repurchasing intentions and implementations, (b) factors affecting abnormal returns and, (c) longrun price performance following repurchasing implementations. The results indicate that the market is indifferent to announcements of repurchasing intentions but responds positively to repurchasing implementations. As for the factors affecting abnormal returns, this study finds that abnormal return responds positively to better prior price performance, dividend yield, directors' holdings, and fraction of shares repurchased. However, abnormal return responds negatively to the previous amount of cash held, reported earnings per share, and market-to-book value. There is no difference in price performance between repurchasing firms and their benchmarks, irrespective of the types of benchmarks being used. This study concludes that there is no difference in price performance between buyback firms and controlled firms in the long-run. Though extant empirical evidence suggests that one of the reasons firms buy back shares is for economic gains, it is evidenced from this study that Malaysian firms do not achieve economic gain in the long run. Further analysis is warranted to determine the real reasons for Malaysian companies to buy back shares. 


\section{References}

Abdul-Latif, R. (2010). Actual share buybacks: Determinants and price effects (Unpublished doctoral dissertation). Universiti Utara Malaysia.

Barber, B. M., \& Lyon, J. D. (1997). Detecting long-run abnormal returns: The empirical power and specification of test statistics. Journal of Financial Economics, 43, 341-372.

Bradford, B. M. (2008). Open-market common stock repurchases and subsequent market performance. The Journal of Business and Economic Studies, 14(1), 45-61.

Chan, K., Ikenberry, D., \& Lee, I. (2004). Economic sources of gain in stock repurchases. Journal of Financial and Quantitative Analysis, 39(3), 461-479.

Comment, R., \& Jarrell, A. G. (1991). The relative signalling power of Dutch-auction and fixed price self tender offers and open market share repurchases. The Journal of Finance, XLVI(4), 1243-1271.

Dann, L. (1981). Common stock repurchases: An analysis of returns to bondholders and stockholders. Journal of Financial Economics, 9, 113-138.

Grullon, G., \& Michaely, R. (2004). The information content of share repurchases programs. The Journal of Finance, LIX (2), 651-680.

Hanita, K. S. (2004). Market reaction on fixed price tender offer shares repurchasing announcement: An analysis of the MAR and SIMM approach. The Malaysian Finance Association 6th Annual Symposium, Langkawi, Malaysia.

Ho, L. J., Liu, C., \& Ramanan, R. (1997). Open-market stock repurchase announcements and revaluation of prior accounting information. The Accounting Review, 72(3), 475-487.

Ikenberry, D., Lakonishok, J., \& Vermaelen, T. (1995). Market under reaction to open market share repurchases. Journal of Financial Economics, 39, 181-208.

Ikenberry, D., Lakonishok, J., \& Vermaelen, T. (2000). Share repurchases in Canada: Performance and strategic trading. Journal of Finance, 55(5), 2373-2397.

Ikenberry, D., \& Vermaelen, T. (1996). The option to repurchase stock. Financial Management, 25(4), 9-24.

Jagannathan, M., \& Stephens, C. (2003). Motives for multiple openmarkets repurchase programs. Financial Management, 32(2), 71-91. 
Jagannathan, M., Stephens C., \& Weishbach, M. (2000). Financial flexibility and the choice between dividends and stock repurchases. Journal of Financial Economics, 57, 355-384.

Jensen, M. C. (1986). Agency costs of free cash flow, corporation finance, and takeovers. The American Economic Review, 76(2), 323-329.

Lie, E. (2002). Do firms undertake self-tender offers to optimize capital structure? The Journal of Business, 75(4), 609-639.

Lim, E. H., \& Bacha, O. I. (2002). Price reaction to stock repurchases: Evidence from the KLSE. Paper presented at the Malaysia Capital Markets: Challenges for the new millennium, Management centre, International Islamic University Malaysia.

Mansor Isa, Zaidi Ghani, \& Swee-Peng Lee. (2011). Market reaction to actual share repurchase in Malaysia, Asian Journal of Business and Accounting, 4(2), 27-46.

Mohamad Jais, Z., \& Chin, Y. F. (2001). The effects of share repurchase announcements in Kuala Lumpur Stock Exchange. Paper presented at the Malaysian Finance Association 3rd Annual Symposium, Kuala Lumpur.

McNally, W. J., \& Smith, B. F. (2007). Long-run returns following open market share repurchases. Journal of Banking and Finance, 31, 703-717.

Nasruddin, Z., \& Angappan, R. (2004). Stated motivation for share repurchasings decision in Malaysia. Bankers Journal, 34-42.

Schipper, K., \& Thompson, R. (1983). Evidence on the capitalized value of merger activity for acquiring firms. Journal of Financial Economics, 11, 85-119.

Stephens, C. P., \& Weisbach, .M. S. (1998). Actual share reacquisitions in open-market repurchase programs. Journal of Finance, 53(1), 313-333.

Vermaelen, T. (1981). Common stock repurchases and market signalling. Journal of Financial Economics, 9, 139-183.

Zhang, H. (2002). Share repurchases under the commercial law 212-2 in Japan: Market reaction and actual implementation. PacificBasin Finance Journal, 10, 287-305.

Zhang, H. (2005). Share price performance following actual share repurchases. Journal of Banking \& Finance, 29, 1887-1901. 